It is Frenchwomen, however, who have the better mortality from all causes, and although the French diet may contain elements that should be emulated, the high mortality from cancer and cirrhosis suggests that the men may have been drinking and smoking to excess compared with the women. More research is needed, and a World Health Organisation study is monitoring trends and determinants for coronary heart disease in 23 countries, including France. ${ }^{17}$

If the digging of the Channel tunnel and the establishment of a true internal market in Europe in 1992 lead to a homogenisation of lifestyles it will be interesting to see whose mortality patterns will predominate.

Professor and Director,

Cardiovascular Epidemiology Unit,

Ninewells Hospital and Medical School, Dundee DD1 9SY

\footnotetext{
1 Smith C, Tunstall-Pedoe $\mathrm{H}$. European regional variation in cardiovascular mortality. Br Med Bull 1984;40:374-9.

2 World Health Organisation. World health statistics annual 1987. Geneva: WHO, 1988.

3 Tunstall-Pedoe H, Smith WCS, Crombie I. Level and trends of coronary heart disease mortality in Scotland compared with other countries. Health Bull (Edinb) 1986;44:153-61.
}

4 Keys A. Seven countries: a multivariate analysis of death and coronary heart disease. Cambridge, Massachusetts: Harvard University Press, 1980

5 Derrienic F, Ducimetière P, Kritsikis S. La mortalité cardiaque des Français actifs d'âge moyen selon leur catégorie socio-professionnelle et leur région de domicile. Rev Epidemiol Sante Publique 1977;25:131-46.

6 Richard JL, Ducimetière P, Bonnaud G, et al. Incidence et évaluation du risque de maladie coronarienne: l'étude prospective parisienne. Arch Mal Coeur 1977;70:531-40.

7 Ducimetière P, Richard JL, Cambien F, Rakotovao R, Claude JR. Coronary heart disease in middle-aged Frenchmen. Comparisons between Paris Prospective Study, Seven Couse in Study, and Pooling Project. Lancet 1980;i:1346-50.

8 Bloch C, Richard JL. Les facteurs de risque des maladies par athérosclérose dans l'Etude Prospective Parisienne. I. Comparaison avec les études étrangères. Rev Epidemiol Sante Publique $1985 ; 33: 108-20$

9 Richard JL, Cambien F, Ducimetière P. Particularités épidémiologiques de la maladie coronarienne en France. Nouvelle Presse Médicale 1981;10:1111-4.

10 Richard JL. Les facteurs de risque coronarien. Le paradoxe français. Arch Mal Coeur 1987;80 (spécial avril):17-21

11 Richard JL, Ducimetière P, Cambien F. Estimation de la mortalité et de la morbidité coronariennes en France à partir de données épidémiologiques. Arch Mal Coeur 1979;72:210-7.

12 St Leger A, Cochrane A, Moore P. Factors associated with cardiac mortality in developed countries with particular reference to the consumption of wine. Lancet 1979;i:1017-20.

13 Keys A. Wine, garlic and CHD is seven countries. Lancet 1980;i:145-6.

14 Buck C, Donner AP, Simpson H. Garlic oil and ischaemic heart disease. Int 7 Epidemiol 1982:11:294-5. A.

15 Renaud S, Morazain R, Godsey F, et ol Nutrients, platelet function and composition in nine groups of French and British Farmers. Atherosclerosis 1986;60:37-48.

16 Gey KF. On the antioxidant hypothesis with regard to arteriosclerosis Bibl Nutr Dieta 1986;37: 53-91.

17 WHO MONICA Principal Investigators (prepared by Tunstall-Pedoe H). The World Health Organisation MONICA Project (Monitoring trends and determinants in cardiovascular disease): a major international collaboration. $\mathcal{F}$ Clin Epidemiol 1988;41:105-14.

\title{
Duodenal ulcers that are difficult to heal
}

\author{
Reinvestigate and change the treatment
}

About $95 \%$ of duodenal ulcers heal during an eight week course of a normal dose of a histamine $\mathrm{H}_{2}$ antagonist.' Some ulcers may not heal because of poor compliance or an unusual regimen of histamine $\mathrm{H}_{2}$ antagonist that does not eliminate nocturnal acidity. Another group of ulcers that are difficult to heal are those caused not by peptic ulceration but by Crohn's disease, tuberculosis, duodenal lymphoma or carcinoma, or cytomegalovirus infection in a patient with AIDS. ${ }^{2}$ Or the ulcer might be caused by the acid hypersecretion of ZollingerEllison syndrome, which is only partly controlled by conventional doses of a histamine $\mathrm{H}_{2}$ antagonist. ${ }^{3}$

Fortunately all these rare causes of duodenal ulceration may be eliminated by one session of intensive investigation. The fasting patient has blood taken for routine haematological and biochemical tests and to measure plasma gastrin concentration and is then sedated with diazepam using the same needle. Gentle questioning at this stage may draw a more honest answer on drug compliance. Upper gastrointestinal endoscopy will allow a view of the duodenum, and any ulceration should be biopsied: all the rare causes of non-peptic duodenal ulceration are diagnosed without difficulty under the microscope. Armed with normal results from these tests the doctor knows that the other causes of an ulcer in the duodenum have been eliminated and that the patient has straightforward refractory peptic ulceration.

All patients with a refractory ulcer should be encouraged to stop smoking and to avoid non-steroidal anti-inflammatory drugs, but should they continue treatment with a histamine $\mathrm{H}_{2}$ antagonist? Most of the evidence suggests that prolonged treatment with conventional doses of cimetidine ${ }^{+5}$ or ranitidine will not work, but possibly larger doses may be useful-for example, cimetidine $1600 \mathrm{mg}$ at night ${ }^{6}$ or ranitidine $300 \mathrm{mg}$ twice daily. ${ }^{7}$ Unfortunately, neither of these regimens has been subjected to a controlled clinical trial in patients with refractory ulcers.

Two studies have suggested that tripotassium dicitrato bismuthate may heal refractory ulcers. ${ }^{89}$ It is not clear how bismuth works but it may clear Campylobacter pylori. ${ }^{10}$ It might thus be worth trying a regimen of tripotassium dicitrato bismuthate plus metronidazole and amoxycillin in these difficult cases. ${ }^{11}$ Misoprostol, a prostaglandin analogue, has been tried with only limited success for refractory ulcers$42 \%$ healed with misoprostol compared with $20 \%$ with placebo. ${ }^{12}$

Omeprazole is not yet available in Britain, but the ability of this inhibitor of hydrogen-potassium adenosine triphosphatase (if given in a dose of at least $30 \mathrm{mg}$ daily) to eliminate all intragastric acidity has achieved virtually total healing of duodenal ulcers after four weeks' treatment. ${ }^{13}$ It might thus be argued that this regimen has eliminated all refractory ulcers, and omeprazole has been tested successfully in two studies of refractory ulceration. ${ }^{51+}$ In a double blind comparative study patients with refractory ulcers were either given omeprazole $40 \mathrm{mg}$ every morning or continued to take histamine $\mathrm{H}_{2}$ antagonist in conventional doses ${ }^{5}$ : after four weeks $87 \%$ of the ulcers in those treated with omeprazole had healed compared with only $39 \%$ of the ulcers in those who continued taking histamine $\mathrm{H}_{2}$ antagonists.

Surgery is not entirely successful for patients with refractory ulcers. A recent study has shown a five year relapse rate of $34 \%$ after highly selective vagotomy in patients with refractory ulcers, whereas the rate was only $3 \%$ in those patients whose ulcers had responded to histamine $\mathrm{H}_{2}$ antagonists before surgery. ${ }^{15}$ There is, however, a suggestion that recurren ulcers in patients who have had unsuccessful highly selective vagotomy do respond to normal doses of a histamine $\mathrm{H}_{2}$ antagonist. $^{16}$

Difficult ulcers may always stay difficult. Delayed healing often seems to be followed by early relapse, and it may be impossible to maintain remission with the usual maintenance dose of a histamine $\mathrm{H}_{2}$ antagonist. ${ }^{14}$ If patients with this type of aggressive ulceration cannot or will not give up smoking 
they may require higher than usual doses of a histamine $\mathrm{H}_{2}$ antagonist, long term omeprazole, or intervention by a surgeon with a special interest in gastric surgery.

ROY POUNDER

Reader in Medicine,

Academic Department of Medicine,

Royal Free Hospital School of Medicine,

London NW3 2QG

1 Chiverton SG, Hunt RH. Medical regimens in short-and long-term ulcer management. Balliere Clin Gastroenterol 1988;ii:655-76.

2 Pounder RE. What is an intractable duodenal ulcer and how should it be managed? Alimentary Pharmacolog $\mathrm{and}$ Therapeutics 1987; 1 ( $\operatorname{suppl} 1): 4395-465$

3 Mignon M, Bonfils S. Diagnosis and treatment of Zollinger-Ellison sỵndrome. Ballieres Clin Gastroenterol 1988;ii:677-98.

4 Bardhan KD. Refractory duodenal ulcer. Gut 1984;25:711-7.

5 Bardhan KD, Naesdal J, Bianchi-Porro G, et al. Treatment of refractory peptic ulcer with omeprazole. Gut 1988;29:A724.

6 Deakin M, Colin-Jones DG, Williams JG. Pharmacological response to cimetidine and healing of duodenal ulceration: effects of high-dose cimetidine and combination of cimetidine with irenzepine. Alimentary Pharmacologv and Therapeutics 1988;2:83-91.

Merki HS, Witzel L, Walt RP, et al. Comparison of ranitidine $300 \mathrm{mg}$ twice daily, $300 \mathrm{mg}$ at nigh and placebo on 24-hour intragastric acidity of duodenal ulcer patients. Alimentary Pharmacology and Therapeutics 1987;1:217-23

8 Lam SK, Lee NW, Koo J, Hui WM, Fok KH, Ng M. Randomised crossover trial of tripotassium dicitrato bismuthate versus high dose cimetidine for duodenal ulcers resistant to standard dose of cimetidine. (jut 1984:25:703-6.

9 Bianchi Porro G, Parente F, Lazzaroni M. Tripotassium dicitrato bismuthate (TDB) versus two different dosages of cimetidine in the treaiment of resistant duodenal ulcers. Gut 1987-28:907-11.

10 Axon ATR. Campylobacter pvlori. In: Pounder RE, ed. Recent advances in gastroenterology-7. Edinburgh: Churchill Livingstone, 1988:225

11 Borsch G, Mai U, Opferkuch W. Oral triple therapy may effectively eradicate Campylobacter pylori in man: a pilot study. (iastroenterology 1988;94:A44.

12 Newmann RD, Gitlin N, Lacayo E, et al. Misoprostol in the treatment of duodenal ulcer refractory to $\mathrm{H}_{2}$-blocker therapy; a placebo controlled multicentre double blind randomised trial. Am $\mathcal{f}$ to $\mathrm{H}_{2}$-blocker therapy; a place

13 Pounder RE. The pharmacological control of gastric acid secretion. In: Pounder RE, ed. Recent advances in gastroenterology-7. Edinburgh: Churchill Livingstone, 1988:245-60.

4 Tytgat GNJ, Lamers CBHW, Hameeteman W, Jansen JMBJ, Wilson JA. Omeprazole in peptic ulcers resistant to histamine $\mathrm{H}_{2}$-receptor antagonists. Alimentary Pharmacology and Therapeutic 1987:1:31-8.

5 Primrose JN, Axon ATR, Johnston D. Highly selective vagotomy and duodenal ulcers that fail to respond to $\mathrm{H}_{2}$ receptor antagonists. Br Med f 1988;296:1031-5.

16 Berstad A, Aadland E, Bjerke $\mathrm{K}$. Cimetidine treatment of recurrent ulcer after proximal gastric vagotomy. Scand f Gastroenterol 1981;16:891-6.

\section{Loans for medical students}

\section{May exclude talented but poorer students}

It is not easy to establish a system of financial support for higher education that reconciles the different and sometimes competing needs of students, families, institutions, and the general public. This government's dissatisfaction with the current grant scheme has led to proposals for loans, an idea first considered 30 years ago by the Anderson committee.' The present white paper describes a non-means tested system of loans to "top up" parental and grant contributions, which will be frozen from 1990. In addition, students will no longer be eligible for income support or unemployment and housing benefits.

The motives behind the plans are not exclusively economic: another intention is to undermine the so-called "dependency culture." The paper claims that the scheme will "contribute to their [the students'] economic awareness and self reliance." The current eroded value of grants might already have let students develop such qualities but, in any case, why should students not be partially dependent during their formative years? The loans scheme will not remove all dependency for many students but merely shift it from one financial agent to another.

Medical education is expensive, and, unlike many students in other faculties, medical students do not have lengthy vacations in which to supplement their income. A recent survey of medical undergraduates found that two fifths had overdrafts and four fifths required supplementary or housing benefits. ${ }^{2}$ The prospect of being dependent on loans for five years (or longer for those at, for example, Cambridge, Oxford, and St Andrews) may well serve as a disincentive to study medicine. This will be particularly true for those from lower income groups, and loan schemes in North America and Scandinavia seem to have discouraged less well off students.' Certainly, the current proportion of medical students from less well off backgrounds cannot have depleted the pool of potential talent from that sector of society. Moreover, the fact that many students regard the selection system as biased does not inspire confidence in the appropriateness of the current composition of the medical student population. ${ }^{3+}$ This is not only an issue of equal opportunities but also one of necessity: as the drop in the proportion of 18-21 year olds affects higher education the need to obtain the best students (including graduates) will be even more compelling.

A loan scheme may still exert important and unintended influences on those who are not deterred from pursuing a medical career. Firstly, it may reduce the number of students who choose to do intercalated degrees and limit the range of options available to students for electives. This matters because they are opportunities for students to develop their full potential and extend their otherwise narrow experience. Secondly, career choice may be partly dictated by the wish to pay off loan debts as quickly as possible rather than to fulfil academic and professional aspirations. Some graduates may thus regard general or private practice as more expedient options than, for example, research. Dormant, unfulfilled aspirations may become a subsequent source of frustration. The impact on career choice may be greater on women, who will have to balance even more carefully than at present the needs of family life and career.

The government has justifiably tried to establish a system of financial support that is "responsive to individuals' economic circumstances," and it advocates that "choice . . . should not be inhibited by an obligation to complete repayment of the loan." I doubt, however, if the proposals will either meet these aims or ensure that medicine does not become the province of privileged students. Whatever form of support is introduced (whether it be an adequate non-means tested grant scheme or a tax based loan scheme that is related to the student's income) it must stimulate the recruitment of those who are able and willing to pursue higher education. Financial support for undergraduates is an investment not a favour extended by the government.

Senior Lecturer in Mental Health,

DAVID A ALEXANDER

Medical School,

Aberdeen AB9 2ZD

1 Baker J, ed. Student loans. The costs and consequences. London: National Union of Students, 1985.

2 British Medical Association. Annual report of the Associate Members Group Committee 1986-7. London: BMA, 1987.

3 Alexander DA, Haldane JDH. Medical education: a student perspective. Med Educ 1979;13:336-41. 4 Alexander DA, Haldane JDH. Medical education: the discontinuers' point of view. Med Educ $1980 ; 14: 16-22$. 